\title{
Analysis of M-REITs Performance Based on Financial Factors and the Degree of Specialization
}

\author{
HANIZA HASHIM ${ }^{1 *}$, NUR BAITI SHAFEE ${ }^{2}$, SHADIA SUHAIMI ${ }^{3}$, SITI NURUL HUDA MOHD ${ }^{4}$, \\ Faculty of Business, Multimedia University, Melaka, MALAYSIA. \\ ${ }^{1}$ E-mail: haniza.hashim@mmu.edu.my \\ ${ }^{2}$ E-mail: norbaiti.shafee@mmu.edu.my \\ ${ }^{3}$ E-mail: shadia.suhaimi@mmu.edu.my \\ ${ }^{4}$ E-mail: huda.mohd@mmu.edu.my
}

\begin{abstract}
The purpose of this research is to analyse the Malaysian Real Estate Investment Trusts (M-REITs) performance based on Financial Factors and Property Characteristics. M-REITs is a relatively new investment vehicle in Malaysia which is slowly soaring. As a developing nation in Asia, Malaysia is currently undergoing vast developments. In this regard, in line with the perpetual development of the Malaysian economy, the significance of M-REITs as a form of investment is also growing, but still far from the establishment state of bonds and stocks. This is attributable to the lack of awareness of the drivers and performance of M-REITs. Previous research on the performance of M-REITs had considered the expected returns as the measure of performance, factoring in financial determinants as well as the property characteristics. Nevertheless, due to the relatively new establishment of M-REITs, only a small sample with limited time series data is available for the examination of the M-REITs. This study seeks to rectify these flaws by employing the latest data of the listed M-REITs to test for the significance of the fir specific determinants of the performance of M-REITs, measured using another proxy termed the funds from operations, of which is a specific measure of M-REITs. The results would then offer inferences about the significance of the firm specific factors on the performance of M-REITs
\end{abstract}

Keywords: Malaysian Real Estate Investment Trusts (M-REITs), performance based on Financial Factors and Property Characteristics

JEL Classification: M3, P34 


\section{Introduction}

This research probes into how financial factors and the degree of specialization affect the performance Malaysian Real Estate Investment Trusts (M-REITs). This part of the chapter provides an overview of the research by covering aspects such as the background of the study, along with the problem statement, research objectives, research questions, significance of the study. The secondary data used in this research comprises information regarding 18 listed M-REITs over a 5-year timeline. The firm-specific factors are retrievable from various documented sources.

\subsection{Background of research}

Real Estate Investment Trusts (REITs) represents a form of investment instrument, which works on the principle whereby tax exempted real estates or properties are owned and managed. REITs are essentially property trust funds that pool funds from investors for the acquisition of properties, which are subsequently operated. The rental income generated from the properties owned are then paid out as dividends to the REIT investors, known as unit holders (Securities Commission Malaysia, 2005). In Asia, Malaysia represents the pioneer to have a public listing of REITs, which was formerly known as property trusts. The investment rates in REITs in Malaysia are significantly lower as compared to other countries in which REITs is an investment option (Newell \& Osmadi, 2009) due to financial factors which comprise size (market capitalisation), book-to-market value (BMV), leverage, and beta.

\subsection{Problem statement}

The performance of REITs, conventionally evaluated based exclusively on the returns, lacked studies that appraise performance based on other equally reliable proxies (Ong, Teh, \& Chong, 2011). Considering the fact that M-REITs are not a popular investment choice, and the adverse perception of Malaysians towards it (Ong, Teh, \& Chong, 2011), an empirical investigation of the firm-specific factor comprising the degree of specialization and financial factors of M-REITs is conducted to assess how these factors are related and the potential impact they have on the performance of M-REITs in terms of funds from operations. In the Malaysian context, studies have been carried out to assess the performance of M-REITs in terms of the different property type. However, the validity of the results are at doubt as M-REITs only got listed on the Bursa Malaysia in 2005 which resulted in a relatively brief period of study, subsequently affecting the reliability of the results for the performance on a long term period. Additionally, the performance of M-REITs were measured solely based on expected returns, which makes the validity of the performance evaluation results rather biased. It is recommended that another measure of performance of REITs, such as the funds from operations, should be adopted to enhance the robustness of the findings (Ong T. S., Teh, Soh, \& Yan, 2012). Past studies concerning the performance of M-REITs are not focused on the degree of specialization of $M$ REITs but rather to the type of property the firm is managing. This indicates that research on the assessment of the degree of specialization of M-REITs on the performance is only a handful and very limited (Jalil \& Ali, 2015). Studies carried out to assess the performance of M-REITs are typically concentrated on only one factor, whilst omitting other significant factors. In other words, previous

studies done have failed to employ other important performance determinants of REITs for the simultaneous performance evaluation of M-REITs (Ping \& Jalil, 2016).

\subsection{Research objectives}

1. To comprehend the relationship between the firm-specific determinants and the performance of M-REITs using funds from operations as a proxy.

2. To identify the extent of influence of the degree of specialization on the performance of $M$ REITs in terms of funds from operations.

3. To determine the degree of impact of financial factors on the performance of M-REITs in terms of funds from operations. 


\subsection{Research Questions}

1. What is the relationship between the firm-specific factors and the performance of M-REITs in terms of funds from operations?

2. How does the degree of specialization affect the funds from operations of M-REITs?

3. How does the market capitalization, book-to-market value, leverage, and beta of M-REITs determine the performance of M-REITs in terms of funds from operations?

\subsection{Significance of study}

The findings and outcomes of this research will look into the areas that are yet to be explored indepth as well as to present a detailed and comprehensive understanding of the factors discussed which are capable of influencing the performance M-REITs. From the perspective of investors, this research presents the various players in the M-REIT industry. Essentially, this research is aimed at building knowledge related to M-REITs to Malaysians in general, to nurture prospective investors aspiring to consider M-REITs as an investment option.

\section{Literature Review}

The literature review plays an essential role of ensuring that this research is based on valid and legit variables, or in the context of this research, determinants, which are capable of influencing the performance of M-REITs. All relevant facts and findings derived from previous studies and dissertations are the basis for this research, and will be further discussed and clarified.

\subsection{Performance of M-REIT, funds from operations (FFO) as proxy}

FFO is essentially depreciation and amortization added to the net income while deducting any gains or losses incurred from the operations (Block, 1997). Traditionally, the FFO has been omitted from the financial statements with only minor disclosure. Till date, as a security governed under the securities exchange commission, REITs are now mandated to have FFO disclosed in the accounting reports to serve as a unit of measurement in accordance to the latest accounting reporting standards (National Association of Real Estate Investment Trusts (NAREIT), 1995). FFO, being a unique accounting item that is not commonly found in most of the books of common securities, is regarded as a unique performance metric that has been established as a standard of the REITs sector. FFO establishes a performance appraisal, which is relatively more informative and not as misleading as the other measures (National Association of Real Estate Investment Trusts (NAREIT), 1997-2006). FFO is more closely associated with the returns of REITs compared to the other measures, which brands FFO as the more informative evaluation tool when it comes to assessing the performance of REITs.

\subsection{Theory}

It has long been in tradition to relate any financial evaluation regarding the performance of stocks or securities of equivalent using the two main approaches. They are known respectively as the Capital Asset Pricing Model (CAPM) and the Fama and French three factor model. CAPM estimate the expected return and Fama and French three factor model employs market capitalization, the book-to-market value, as well as the degree of leverage in the derivation of returns (Fama \& French, 1995).

\subsubsection{Degree of specialization}

REITs with portfolio of $75 \%$ or more invested in a variety of property type are classified as diversified (Ambrose B. W., 2001). Past research have demonstrated that in the United States where REITs are established and flourished, a minority of REITs are diversified by property type whereas the mass of REITs are specialized in either a single property or two property types, which are similar in nature (National Association of Real Estate Investment Trusts (NAREIT), 1997-2006). Furthermore, several research had been conducted to investigate relationship of REITs of healthcare property type and 
performance, study on hotel REITs, and residential REITs. The varying type of real estate resulted in the difference in performance of REITs. Taking this principle into application, a diversified REIT portfolio constituting of REITs engaged in different property types is potentially influential on the performance in the sense that the effect of diversification is reflected in the performance (Myer, Neil, \& Webb, 2000).

\subsubsection{Market Capitalization}

REITs of different property sector are often classified based on the sizes; in which it is evaluated according to a proxy known as the market capitalization (market cap). Market capitalization has long been a component used to derive the returns of stocks in the sense that the size of the firm issuing that particular stock is somewhat influential towards the returns (Colwell \& Park., 1990). The underlying question of the effect of firm size (market cap) to the returns of REITs remain unresolved today. Nevertheless, market capitalization, as is demonstrated by past studies, is highly correlated with REITs returns (Hishamuddin Mohd Ali, 2006). In addition to the aforementioned notion of returns as a reliable measurement of performance, market capitalization, being an influential factor of returns is thus, viewed as a significant determinant of the performance of REITs.

\subsubsection{Book to market value}

The book to market value (BMV) has been traditionally associated with the performance of stocks. The significance of BMV in explaining the performance of REITs is linked to the adoption of it as a determinant of the performance of securities in terms of returns (Datar, Naik, \& Radcliffe., 1998). A study by Chui, Titman, \& Wei (2003) indicated that BMV proved to be an appropriate forecasting item of future returns of stocks. The financial attributes of firms owning and managing REITs, including the market capitalization, degree of financial leverage, as well as the BMV, played a vital role in determining the performance behaviour of REITs (Yong, Allen, \& Lim, 2009).

\subsubsection{Leverage}

Leverage ratio reflects the financing choice of an organization, as well as the capital raised by an organization in establishing the financing structure. Degree of leverage employed by organizations are subjected to fluctuations attributable to the change in need of debt levels, evidence from Lemmon, Roberts, \& Zender (2008) shows that the degree of leverage are in some organizations, relatively consistent over the period. significance of levered REITs as opposed to unlevered REITs in affecting the performance in terms of returns was displayed (Giacomini, Ling, \& Naranjo, 2014). In this regard, levered REITs demonstrated higher volatility as well as returns compared to unlevered REITs. Relative to this finding, it was found that within levered REITs, those that are leveraged higher than the targeted leverage level outperformed the lowly levered ones, which is coincidentally consistent with the notion of the positive correlation between the degree of leverage and performance (Giacomini, Ling, \& Naranjo, 2015).

\subsubsection{Beta}

Beta coefficient translates to the international beta, which represents an indicator of the volatility and systematic risk of a particular REIT in comparison to the nation's REIT market as a whole. The development of the beta coefficient is evident as it represents a component used in deriving the risk premium of a security. Past research showing correlation between systematic risk and the performance of REITs is evident in the work of Kok \& Khoo (1995), which analysed the performance of REITs in different periods classified into upward market, downward market, and over-speculated market. The relationship between beta and REIT performance was concluded to be significant as the changes of the beta coefficient of REITs 


\section{Methodology/Materials}

\subsection{Overview}

This chapter discussed in detail the methodology employed to examine the relationship between each individual independent variable with the dependent variable. The research hypotheses are assumptions made with association to the research objectives and research questions to indicate the relationship between the performance of M-REITs and the degree of specialization, market capitalization, book-to-market value, leverage, and beta.

\subsection{Development of theoretical framework and hypotheses}

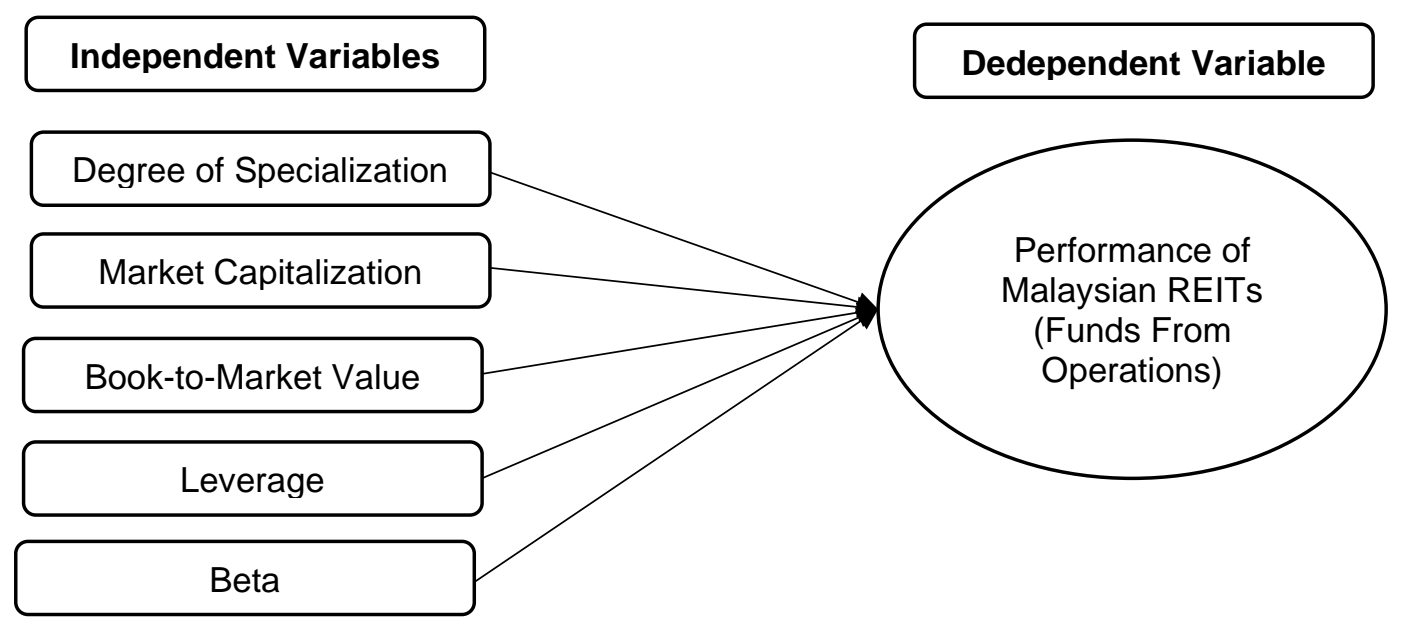

\subsection{Hypothesis}

Hypothesis 1, H1: The relationship between the degree of specialization and the performance of M-REITs is significant.

Hypothesis 2, H2: The relationship between the market capitalization and the performance of $\mathrm{M}$ REITs is significant.

Hypothesis 3, H3: The relationship between the book-to-market value and the performance of MREITs is significant.

Hypothesis 4, H4: The relationship between the leverage and the performance of M-REITs is significant.

Hypothesis 5, H5: The relationship between beta and the performance of M-REITs is significant.

\subsection{Research Design}

The primary aim of this research is to examine the relationship between the independent variables, which are the firm-specific determinants and the dependent variable, represented by the performance of M-REITs measured in terms of funds from operations through the means of hypothesis testing. A quantitative approach is employed to arrive at the results of this research, which subsequently provides a comprehension towards the relationship between the independent variables and the dependent variable. The sample of this research is represented by the 18 listed real estate investment trusts in Malaysia. These 18 listed M-REITs are namely AmFirst Real Estate Investment Trust, Axis Real Estate Investment Trust, AmanahRaya Real Estate Investment Trust, Atrium Real Estate Investment Trust, CapitaLand Malaysia Mall Trust, Al-'Aqar Healthcare REIT, Al-Salam Real Estate Investment Trust, Tower Real Estate Investment Trust, Hektar Real Estate Investment Trust, IGB Real Estate Investment Trust, KIP Real Estate Investment Trust, KLCC Real Estate Investment Trust, Pavilion Real Estate Investment Trust, Amanah Harta Tanah PNB, YTL Hospitality REIT, MRCB-Quill REIT, Sunway Real Estate Investment Trust, and UOA Real Estate Investment Trust 


\section{Results and Findings}

\subsection{Descriptive Statistics}

Table1: Model for Paper

\begin{tabular}{|c|c|c|c|c|c|}
\hline Variables & Observations & Mean & Std. Dev. & Maximum & Minimum \\
\hline Market Cap & 76 & 6.7871 & 1.1360 & 8.6557 & 4.5799 \\
\hline Leverage & 77 & 3.9935 & 1.9536 & 8.6557 & -4.0009 \\
\hline BMV & 76 & 1.0610 & 0.2960 & 1.7080 & 0.0117 \\
\hline Beta & 74 & -17.042 & 54.6226 & 39.2361 & -232.1161 \\
\hline SPEC & 90 & 0.3333 & 0.4740 & 1 & 0 \\
\hline
\end{tabular}

Based on table 1 , due to the absence of data for certain firms in certain period of time, data analysed were not on the original sample size of 90 . Under market capitalization, only 76 observations were recorded, the same number applies to the book-to-market value variable. As for leverage, 77 observations were recorded, whereas the beta variable only resulted in a record of 73 observations. Data on the degree of specialization of the 18 Malaysian REITs in discussion were available for all firms throughout the stipulated period which successfully resulted in a complete observation of 90 . In terms of the size of the firm represented by market capitalization, the mean of the market cap of the 18 Malaysian REITs in discussion amounted to 6.7871, while the standard deviation amounted to 1.1360, with the maximum market cap going as high as 8.6557, and the lowest as low as 4.5799. The leverage or gearing used registered a mean of 3.9935, while the standard deviation stands at 1.9536, with the highest leverage used standing at 8.6557, and the lowest at -4.0009 . As for the book-to-market value, a mean of 1.0610 was identified, with the standard deviation standing amounting to 0.2960 . The maximum value of the book-to-market value of the sample was 1.708 , and the minimum value at 0.0117 . With regard to the beta, a negative mean of -17.0419 was resulted, with the standard deviation value at 54.6226. A maximum value of the beta is 39.2361 , while the minimum value going as low as 232.1161. The degree of specialization on the other hand is of exception as the qualitative nature of the data were quantified into 0 representing specialized and 1 representing diversified, hence the insignificance of the mean of 0.3333 and standard deviation of 0.4740 generated.

\subsection{Multicollinearity Test}

Table 2. Multicollinearity Test

\begin{tabular}{|c|c|c|c|c|c|}
\hline & Market Cap & Leverage & BMV & Beta & Spec \\
\hline Market Cap & 1.0000 & & & & \\
\hline Leverage & 0.2990 & 1.0000 & & & \\
\hline BMV & -0.6285 & -0.1160 & 1.0000 & & \\
\hline Beta & -0.2002 & -0.1768 & 0.0989 & 1.0000 & \\
\hline Spec & -0.0579 & -0.0602 & -0.0827 & 0.0307 & 1.0000 \\
\hline
\end{tabular}

The identification of a linear relationship among the independent variables in a model would render multicollinearity evident. In this regard, the multicollinearity test is employed as a method for detecting the existence of a relationship among the independent variables. Following the identification of a relationship, the strength of the relationship is ascertained via the correlation matrix. In relation to that, table 4.2 serves as a depiction to display the results of the application of the correlation matrix on the model. With reference to table 4.2, the results of the correlation as well as the strength of correlation between the independent variables in discussion, namely market capitalization, leverage, book-to-market value, beta, and degree of specialization is shown. 


\subsection{Hausman Test}

Table 3. Hausman Test

\begin{tabular}{|c|c|c|c|c|}
\hline \multirow{2}{*}{ Variables } & \multicolumn{2}{|c|}{ Coefficients } & Difference & Square Root \\
\cline { 2 - 5 } & b & B & b-B & V_b - V_B \\
\hline Market Cap & 0.4177 & 0.9005 & -0.4827 & 0.4671 \\
\hline Leverage & 0.1323 & 0.0545 & 0.0778 & 0.0574 \\
\hline BMV & 0.1946 & 0.2427 & -0.0481 & 0.5724 \\
\hline Beta & -0.0001 & -0.0003 & 0.0001 & 0.0006 \\
\hline
\end{tabular}

The focal point of this research is on the degree of specialization and the financial factors that determines the performance of Malaysian REITs throughout the period of 2012 to 2016, with a panel data sample used for the assessment of Malaysian REITs performance over the specified time span. With regard to this, the Hausman Test is employed to distinguish the nature of the panel data in terms of whether it is of a fixed effect or a random effect. Based on table 3, considering that the p-value of 0.4291 is greater than the $0.05(5 \%)$ significant level, it is concluded that the model is classified as a Random effect Model.

\subsection{Inferential Analysis}

Table 4. Inferential Analysis

\begin{tabular}{|c|c|c|c|}
\hline Independent Variable & Coefficient Value & p-value & Correlation \\
\hline Market Capitalization (MCAP) & 0.9005 & 0.000 & + , significant \\
\hline Leverage (LEV) & 0.0545 & 0.065 & + , insignificant \\
\hline Book-to-market Value (BMV) & 0.2427 & 0.375 & + , insignificant \\
\hline Beta (BETA) & -0.0003 & 0.518 & - -, insignificant \\
\hline Degree of Specialization (SPEC) & 0.1697 & 0.099 & + , insignificant \\
\hline
\end{tabular}

Based on the fact and figures depicted by table 4.6 , at the $5 \%$ level of significance, only the market capitalization appeared to be significant to the performance of Malaysian REITs in terms of funds from operations, while all other independent variables such as the leverage, book-to-market value, beta, and degree of specialization are insignificant to said performance. This translates to the fact that only market capitalization is relevant in affecting the performance of Malaysian REITs.

\section{Conclusion}

\subsection{Findings}

The positive and significant result of the market capitalization to the performance of M-REITs indicate that for every increase in a unit of market capitalization, the funds from operations increases by 0.9005 units, ceteris paribus. The implication of this is that as the establishment of M-REITs grows larger in terms of market size which is measured by the market capitalization, the capacity to generate cash purely from operations follows suit. In other words, the growth in funds from operations are proportionate to the growth in market size. The significant effect of firm size to the performance of $\mathrm{M}$ REITs as is shown in the results of this study corresponds to the empirical findings of Hishamuddin Mohd Ali (2006), Mclntosh, Liang, \& Tompkins (1991), Ambrose B. W. (2001) and Below, Stansell, \& Coffin (2000). The insignificant outcome of the leverage to performance shows that there is no convincing evidence to indicate that the amount of debt used relative to the equity of a particular $\mathrm{M}$ REIT is influential on the fund generating capacity. This explicitly means that contrary to studies by Fairchild, MacKinnon, \& Rodrigues (2011) on REITs listed in the New York Stock Exchange, the adoption of a high gearing ratio does not necessarily amplifies the funds generated from operations. Another attributable reason by Ippolito, Filippo, Steri, \& Tebaldi (2012) is that the effect of leverage on the 
funds from operations essentially depends on the deviation from the target leverage. Results of this study showed no apparent significance between the book-to-market value and the funds from operations. Empirical studies by Daniel, Hirshleifer, \& Subrahmanyam (1998) have suggested that the book-to-market value, associated to growth, often plays a role in determining the fund generating capacity of a REIT, only when put in terms of returns. Therefore, this valuation variable of M-REITs, according to the results of this study and findings by Datar, Naik, \& Radcliffe (1998) is asserted to be insignificant to the funds from operations unless expressed in the form of a return. Results also verified that beta, a denotation of the systematic risk a particular M-REIT presents, plays no role in determining the funds from operations generating capacity. Jahankhani \& Lynge (1980) study on New York Exchange listed REITs demonstrated that REITs with higher risk profile yielded higher dividends, which is an outcome of higher fund generating capacity. However, under the context of this study, when assessed exclusively on the funds from operations, results showed otherwise, which corresponds to the findings of Delcoure \& Dickens (2004) and Murthi, K.Choi, \& Desai (1997).

\subsection{Implications}

The results of this study offer some insights into firm-specific factors and the performance of $M$ REITs while defining the degree of impact these factors have on the performance of M-REITs evaluated by the funds from operations. The findings provide researchers and readers an idea of the potential impacts of financial factors and the degree of specialization on the performance of M-REITs in terms of funds from operations. On an individual level, the attributes of a particular M-REIT which possesses the capacity to generate adequate funds from operations is made known. In essence, this means the trait for a well performing M-REIT. On an organizational level, the results offer some input into the determination of a financial strategy for a certain M-REIT portfolio. Be that as it may, the results also indicated that there are other aspects to factor in while employing the stipulated determinants in assessing the performance of M-REITs. On a global context, the results of this research serve as a comparison to other REITs of other countries. In this regard, the employment of the same variables namely market capitalization, leverage, book-to-market value, beta, and the degree of specialization has evidently resulted in a different outcome as opposed to REITs of other nations, namely America, as was discussed under Chapter 2- literature review of this research. What was apparently significant to the operations funds generating capacity of those REITs were insignificant in Malaysia.

\subsection{Limitations}

The absence or non-disclosure of data for certain years and for certain REITs which are unattainable from the Bloomberg database as well as the financial statements narrowed the rightful observation from 90 to 76. Additionally, due to the relatively new establishment of REITs in Malaysia, as well as the small number of listed REITs, 18 to be exact, the information and data obtained are forced to be limited. Hence, this may potentially be a source of distortion of results and subsequently the findings, as opposed to a study on larger number and longer duration of REITs which have a long record of establishment, as is seen in the case of REITs is developed economies. In terms of sample size, the results are confined to the Malaysian context. It is worth noting that REITs of different countries behave and perform distinctively. Therefore, the findings and implications of this research are only meaningful in the Malaysian context. Any usage of the results of this research under a context besides Malaysia can only be applied as a reference. Another limitation to this research is the exclusion or omission of other relevant financial factors. The financial factors employed is this research, comprising market capitalization, leverage, book-to-market value, and beta represents the most common and extensively used financial factors or determinants when examining financial performance. This is said with reference to empirical studies, hence the use of these variables. Nevertheless, there are in fact other firm-specific factors which are influential towards the performance of REITs which are not employed in the study. Additionally, the historical results employed may not be accurate in determining future correlations. 


\subsection{Recommendations}

Future research can consider including more firm-specific variables or financial factors which are influential on both the long-term and short-term performance of REITs regardless of the impact magnitude of each variable. This is particularly so as to identify specifically the determinants which impact the performance of REITs in Malaysia, which are further distinguished into long-term and shortterm. On top of that, future research can be geared towards the utilization of high frequency data entailing monthly or quarterly data for the enhancement of robustness of the study. It is also recommended that multiple proxies be adopted to enhance the robustness of the study. In this regard, the set of determinants can be tested on various proxies to ascertain the validity of the effects they have on the dependent variable. In relation to that, future studies pertaining to this topic could employ a larger sample size or more observations by including sub samples comprising of unlisted REITs, which are equally gaining popularity. Given the relatively new nature of REITs in Malaysia, data for a complete decade is yet to be available. Nonetheless, the near future will mark the 10 year establishment of Malaysian REITs, which would render future studies data of a longer time period for the attainment of a more accurate analysis result. The relatively small sample size may be a contributory factor to data constraints thus leading to potential unreliability. Additionally, other tests can be applied in future studies to further verify and emerge with a more precise reliability measurement of the variables. On another spectrum, a comparative analysis between the performance of Malaysian REITs and the performance of REITs of another nation of the same economic status based on the same set of variables can be carried out to identify whether the designated variables represent the only influential factor or is the performance attributable to some other macro-level components.

\subsection{Conclusion}

Motivated primarily by the relatively new nature of Malaysian REITs, this study serves to understand the relationship between firm-specific determinants and the financial performance of Malaysian REITs. Specifically, the market capitalization, leverage, book-to-market value, beta, and the degree of specialization are tested to assess the influential magnitude these variables have on the performance of Malaysian REITs, measured in terms of funds from operations instead of the traditional used proxies in the period of 2012 to 2016. Empirical studies on the said subject were scrutinized to emerge with an in-depth comprehension of REITs. Following that, the research methodology which demonstrates the methods of obtaining and analysing the data sample is shown. The panel data regression model was applied, subsequently, the STATA software was used to run the analysis to arrive at the results which are interpreted and presented under the findings. The results of the statistical analysis suggested that market capitalization contributes significantly and positively to the performance of Malaysian REITs, while the leverage, book-to-market value, beta, and degree of specialization are statistically insignificant to the performance of the Malaysian REITs, not at least in the sense of funds from operations.

\section{References}

1. Ambrose, B.W. (2001). REIT organizational structure and operating characteristics. Journal of Real Estate Research, 21(3), 141-162.

2. Below, S., Stansel, S., \& Coffin, M. (2000). The Determination of REIT Institutional Ownership. Journal of Real Estate Finance and Economics, 263-278.

3. Block, R.L. (1997). The Essential REIT: A Guide of Profitable Investing in Real Estate Investment Trusts. Journal of Accounting Research, 1-48.

4. Chui, A.C., Titman, S., \& Wei, K.J. (2003). The Cross-Section of Expected REIT Returns. Real Estate Economics.

5. Colwell, P.F., \& Park., H.Y. (1990). Seasonality and Size Effects: The Case of Real-Estate-Related Investment, Journal of Real Estate Finance and Economics,251-260. 
6. Daniel, K.D., Hirshleifer, D., \& Subrahmanyam, A. (1998). Investor Psychology and Security Market Under and Overreactions. Journal of Finance 53, 1839-85

7. Datar, T.V., N.Y., \& Radcliffe., R. (1998). Liquidity and Stock Returns: An Alternative Test. Journal Financial Markets 1, 203-219.

8. Firchild, S., MacKinnon,G., \& Rodrigues.,J. (2011). Are All Open-End Core Funds Created Equal? The Journal of Portfolio Management, Vol. 37, No. 5, 51-67.

9. Giacomini, E., Ling, D.C., \& Naranjo, A. (2014). Leverage and Returns: A Cross-Country Analysis of Public Real Estate Markets.

10.Giacomini, E., Ling, D.C., \& Naranjo, A. (2015). Optimal Capital Structure and The Effects of Deviation From Target.

11. Hishamuddin Mohd Ali, P. (2006). Size Effects on the Performance of Listed Real Estate Companies. 12.Ippolitto, Filipo, Steri, R., \& Tebaldi, C. (2012). The Relative Leverage Premium. SSRN Working Paper. 13.Jalil, R.A., \& Ali, H.M. (2015). Performance Determinants of Malaysian Real Estate Investment Trusts. Journal of Technology.

14.Kok, K., \& Khoo, K. (1995). Performance of Property Trusts in the Kuala Lumpur Stock Exchange. Capital Markets Review, 1-19.

15.McIntosh, W., Liang, Y., \& Tompkins, D.L. (1991). An Examination of the Small Firm Effect within the REIT Industry. Journal of Real Estate Research Vol 6, No. 1, 9-17.

16.Myer, Neil, F.C., \& Webb, J.R. (2000. Management Styles of REIT Funds. Journal of Real Estate Portfolio Management, 6(4): 339-348.

17. National Association of Real Estate Investment Trusts (NAREIT). (1995). White Paper: Funds From Operations.

18. Newel, G., \& Osmadi, A. (2009). The Development and Prelimary Performance Analysis of Islamics REITS In Malaysia. Journal of Property Research, 329-347.

19.Ong, T.S.,Teh, B.H., \& Chong, M.P. (2011). A Study On The Performance Of Malaysian Real Estate Investment Trusts From 2005-2010 By Using Net Asset Value Approach. International Journal of Economics and Research, 1-15.

20.Ong, T.S.,Teh, B.H., Soh, C.H., \& Yan, Y.L (2012). Malaysian Real Estate Investment Trusts: A Performance and Comparative Analysis. International Journal of Economics and Finance.

21.Ping, T.C., \& Jalil, R.A. (2016). Property types diversification strategy of Malaysian Real Estate Investment Trust (M-REITs).

22.Securities Commission Malaysia. (2005). Guidelines on Real Estate Investment Trusts.

23.Yong, J., Allen, D.E., \& Lim, L.K. (2009). A REIT returns from 1990-2008: A multi-factor approach. $1522-1529$. 